\title{
PENERAPAN AKUNTANSI PPh PASAL 23 ATAS JASA AGEN PADA PT. AJB BUMIPUTERA 1912 CABANG MANADO
}

\author{
Cicilia Luas ${ }^{1}$, Treesje Runtu ${ }^{2}$, Victorina Z. Tirayoh ${ }^{3}$ \\ ${ }^{1,2,3}$ Fakultas Ekonomi dan Bisnis, Jurusan Akuntansi, Universitas Sam Ratulangi, Jl.Kampus Bahu, Manado, \\ 95115, Indonesia \\ email: cicilialuas@gmail.com
}

\begin{abstract}
In the state budget of revenues and expenditures (APBN), it can be seen that the target of state revenue from the tax sector has increased from year to year. APBN 2016 shows tax revenue accounted for about $84 \%$ of total state revenues as a whole. Therefore, Canit is said that taxes play a vital role in the financing of national development. Object in this research is PT. AJB BUMIPUTERA 1912 which is engaged in life insurance. The purpose of this study is to find out how the application of accounting PPh article 23 for servicesagent at PT. AJB BUMIPUTERA 1912 Manado branch. Method of data analysis used in this research is discussing problem by colleting, elaborating, counting, and comparing a situation and explaining a situation so that can be drawn conclusion.
\end{abstract}

Keywords: accounting, income tax article 23

\section{PENDAHULUAN}

Indonesia bercita-cita untuk melindungi segenap warganegara, memajukan kesejahteraan umum, mencerdaskan kehidupan bangsa dan ikut serta dalam melaksanakan ketertiban dunia. Untuk mencapai cita-cita tersebut, pemerintah Indonesia melaksanakan pembangunan di segala bidang dan berupaya untuk mewujudkan kemandirian dalam pembiayaan pembangunan tersebut. Kemandirian yang dimaksud adalah memanfaatkan kemampuan dalam negeri melalui peningkatan penerimaan Negara dari berbagai sector dan tidak bergantung lagi pada pinjaman luar negeri.

Salah satu sumber penerimaan negara yang paling besar dan potensial saat ini adalah pajak. Pajak menurut Pasal 1 Undang-Undang No. 28 Tahun 2007 Perubahan Ketiga Atas Undang - Undang Nomor 6 Tahun 1983 Tentang Ketentuan Umum dan Tata Cara Perpajakan, merupakan kontribusi wajib kepada negara yang terutang. Untuk memaksimalkan penerimaan pajak, Dirjen pajak perlu untuk memperbaharui peraturan-peraturan perpajakan.Peraturan pajak juga ikut mempengaruhi keputusan-keputusan bisnis baik secara langsung maupun tidak langsung. Salah satunya adalah pada perusahaan asuransi.Saat ini industri asuransi sangat menarik perhatian masyarakat karena memberikan manfaat untuk tabungan dan investasi.

Kombinasi produk asuransi dengan tabungan ataupun dengan investasi ini akan memberikan manfaat yang dikaitkan dengan hidup dan meninggalnya orang yang dipertanggungkan, berdasarkan perkembangan ini maka Dirjen Pajak memperbaharui sekaligus mempertegas peraturan-peraturan pajak yang berlaku. Industri asuransi juga memiliki karakteristik yang berbeda dengan industry jasalainnya.Pendapatan dalam usahaa suransi diketahui dan terjadi lebih dahulu, sementara beban klaim merupakan beban utama industry asuransi yang belum terjadi.Karena itulah industry asuransi sangat dipengaruhi oleh unsure e estimasi dan ketidakpastian.Kegiatan operasional perusahaan untuk mendapatkan,menagih serta memelihara pendapatan tersebut tentunya tidak luput atas pengenaan pajak. Banyaknya pihak yangt terlibat dalam operasionalisasi diatas, menyebabkan perusahaan harus memperhatikan pemotongan dan pemungutan pajak untuk disetorkan kepada negara.Salah satu 
perusahaan asuransi jiwa yang sedang tumbuh pesat saat ini adalah PT. AJB Bumiputera 1912.Sampai dengan akhir tahun2016, produk asuransi jiwa PT. AJB Bumiputera 1912 telah dipasarkan melalui agen-agen asuransi jiwa diseluruh wilayah Indonesia. Agen asuransi ini memiliki peranan yang penting terhadap pendapatan perusahaan untuk mendapatkan jumlah premi yang maksimal.Diharapkan agen asuransi ini dapat mencapai jumlah premi yang sudah ditargetkan perusahaan demi tumbuhnya pendapatan perusahaan Pengelolaan premi yang disetorkan oleh pemegang polis pun tidak terlepas dari pemotongan pajak premi atas hasil investasi preminya.

\section{TINJAUAN PUSTAKA}

\subsection{Konsep Akuntansi}

Menurut Suwardjono (2011), akuntansi adalah seperangkat pengetahuan dan fungsi

yang berkepentingan dengan masalah pengadaan, pengabsahan, pencatatan, pengklasifikasian, pemrosesan, peringkasan, penganalisisan, penginterpretasian dan penyajian secara sistematik informasi yang dapat dipercaya.

\subsection{Konsep Pajak}

Pajak adalah iuran kepada negara yang dapat dipaksakan) yang terutang oleh yang wajib membayarnya menurut peraturan perundangan dengan tidak mendapat prestasi kembali secara langsung untuk meambiayai pengeluaran pabrik ( R.S. Brotodiharjo (2003:2).

\subsubsection{Pajak Penghasilan PPh}

Menurut Mardiasmo (2011;135), undang-undang Pajak Penghasilan mengatur pengenaan Pajak penghasilan terhadap subjek pajak berkenaan dengan penghasilan yang diterima atau diperolehnya dalam tahun pajak. Subjek Pajak tersebut dikenai Pajak apabila menerima atau memperoleh Penghasilan.Subjek Pajak yang menerima atau memperoleh penghasilan, dalam Undang-Undang PPh disebut Wajib Pajak. Wajib Pajak dikenai pajak atas penghasilan yang diterima atau diperolehnya selama satu tahun pajak atau dapat pula dikenai pajak untuk penghasilan dalam bagian tahun pajak apabila kewajiban pajak subjektifnya dimulai atau berakhir dalam tahun pajak.

\subsubsection{Objek Pajak Penghasilan}

Mardiasmo (2011) yang menjadi objek pajak adalah penghasilan, yaitu setiap tambahan kemampuan ekonomis yang diterima atau diperoleh Wajib Pajak, baik yang berasal dari Indonesia maupun dari luar Indonesia termasuk:

a. Penggantian atau imbalan berkenaan dengan pekerjaan atau jasa yang diterima atau diperoleh termasuk gaji, upah, tunjangan, honorarium, komisi, bonus, gratifikasi, uang pensiun atau imbalan dalam bentuk lainnya kecuali ditentukan lain dalam Undangundang;

b. Laba usaha;

c. Keuntungan karena penjualan atau karena pengalihan harta termasuk:

1. Keuntungan karena pengalihan harta kepada perseroan, persekutuan dan badan lainnya sebagai pengganti saham atau penyertaan modal;

2. Keuntungan karena likuidasi, penggabungan, peleburan, pemekaran, pemecahan, pengambilalihan usaha, atau reorganisasi dengan nama dan dalam bentuk apapun;

\subsection{Pajak Penghasilan Pasal 23}

Menurut UU RI No.16 Tahun 2008 yang dikutip oleh Thomas Sumarsan (2012 : 301), Pajak Penghasilan (PPh) 23 adalah pajak yang dipotong atas penghasilan yang berasal dari modal, penyerahan jasa, atau hadiah dan penyelenggaraan kegiatan, selain yang telah dipotong PPh Pasal 21.

\subsubsection{Tarif Pajak Penghasilan (PPh) Pasal 23}

Tarif PPh Pasal 23, baik yang 15\% maupun yang 2\% dikenakan terhadap jumlah bruto. Dengan demikian, dasar pengenaan PPh Pasal 23 adalah jumlah bruto.Sebelum tahun 
2009, atas penghasilan selain dividen, bunga, sewa, royalti dan hadiah serta penghargaan, dikenakan tarif $15 \%$ dari perkiraan penghasilan neto.Besarnya perkiraan penghasilan neto tiap-tiap jenis penghasilan biasanya berlainan sehingga tarif efektifnya juga menjadi berlainan. Saat ini pengenaan PPh Pasal 23 menjadi sederhana dan mudah karena hanya mengenakan tarif langsung terhadap jumlah bruto.

Namun demikian, dalam praktek di lapangan sering terjadi perbedaan pemahaman tentang apa yang dimaksud dengan jumlah bruto. Tidak ada penjelasan tentang arti jumlah bruto ini baik di batang tubuh maupun di penjelasan Undang-undang Pajak Penghasilan. Hal ini sangat terasa terutama ketika akan menerapkan tarif $2 \%$ untuk objek PPh Pasal 23 berupa imbalan jasa teknik, jasa manajemen, jasa konsultan dan jasa lain. Berdasarkan Surat Edaran ini, yang dimaksud dengan jumlah bruto adalah seluruh jumlah penghasilan dengan nama dan dalam bentuk apapun yang dibayarkan, disediakan untuk dibayarkan, atau telah jatuh tempo pembayarannya oleh badan pemerintah, subjek pajak badan dalam negeri, penyelenggara kegiatan, bentuk usaha tetap, atau perwakilan perusahaan luar negeri lainnya kepada Wajib Pajak dalam negeri atau bentuk usaha tetap, tidak termasuk:

1. Pembayaran gaji, upah, honorarium, tunjangan dan pembayaran lain sebagai imbalan sehubungan dengan pekerjaan yang dibayarkan oleh Wajib Pajak penyedia tenaga kerjakepada tenaga kerja yang melakukan pekerjaan, berdasarkan kontrak dengan pengguna jasa. Atas pembayaran ini harus dibuktikan dengan kontrak kerja dan daftar pembayaran gaji, upah, honorarium, tunjangan dan pembayaran lain sebagai imbalan sehubungan dengan pekerjaan.

2. Pembayaran atas pengadaan/pembelian barang atau material. Atas pembayaran ini harus dibuktikan dengan faktur pembelian barang atau material.

3. Pembayaran kepada pihak kedua (sebagai perantara) untuk selanjutnya dibayarkan kepada pihak ketiga. Atas pembayaran ini harus dibuktikan dengan faktur tagihan dari pihak ketiga disertai dengan perjanjian tertulis.

4. Pembayaran penggantian biaya (reimbursement) yaitu penggantian pembayaran sebesar jumlah yang nyata-nyata telah dibayarkan oleh pihak kedua kepada pihak ketiga. Atas pembayaran ini harus dibuktikan dengan faktur tagihan atau bukti pembayaran yang telah dibayarkan oleh pihak kedua kepada pihak ketiga.

\subsection{Tujuan Asuransi}

Menurut M. Nur Rianto (2012:212) asuransi merupakan sebuah mekanisme perlindungan terhadap pihak tertanggung apabila mengalami resiko dimasa yang akan datang dimana pihak tertanggung akan membayar premi guna mendapatkan ganti rugi dari pihak penanggung.

\section{METODE PENELITIAN}

\subsection{Jenis dan sumber data}

Data merupakan sekumpulan informasi yang didapat dari sebuah penelitian untuk kemudian digunakan dalam menganalisa permasalahan yang dihadapi dan pada akhirnya mencari solusi sebagai pemecahan. Jenis data yang dipergunakan dalam penelitian ini, yaitu:

1. Data Kualitatif, yaitu data yang disajikan secara deskriptif atau terbentuk uraian seperti :sejarah singkat perusahaan, struktur organisasi dan job description, dokumen-dokumen, sertaUndang - undang dan peraturan-peraturan yang berkaitan dengan PPh pasal 23.

2. Data Kuantitatif, yaitu data yang disajikan dalam bentuk angka - angka atau bilangan yang dapat dihitung dan dapat di bandingkan yang satu dengan yang lainnya. Data-data tersebut berupa penghitungan $\mathrm{PPh}$ pasal 23.

Sumber data dalam penelitian ini, yaitu : 
1. Data Primer, yaitu data yang diperoleh langsung oleh penulis dari objek penelitian dengan cara wawancara, dan data yang diambil dari perusahaan seperti daftar perhitunganPPhpasal 23.

2. Data Sekunder, yaitu data yang berasal dari sumber atau pengamatan lain. Contohnya: buku - buku literatur yang digunakan sebagai acuan, jurnal penelitian, Undang - undang dan peraturan tentang PPh Pasal 23serta data pendukung lainnya.

\subsection{Metode Analisis}

Metode analisis data yang digunakan dalam penelitian ini adalah metode deskriptif, yaitu membahas masalah dengan cara mengumpulkan, menguraikan, menghitung, dan membandingkan suatu keadaan serta menjelaskan suatu keadaan sehingga dapat ditarik kesimpulan yang meliputi pemotongan dan pemungutan pajak penghasilan PPH Pasal 23 dalam perusahaanAsuransi Jiwa pada PT. AJB Bumiputera 1912).

\subsection{Definisi Operasional}

Sesuai dengan judul penelitian yaitu : "Penerapan Akuntansi PPh pasal 23 atas Jasa Agen pada PT. AJB Bumiputera 1912 Cabang Manado" maka perlu dijelaskan arti dari judul adalah sebagai berikut :

1. Penerapan adalah suatu usaha yang dilakukan secara mendetail mengetahui suatu objek yang akan diteliti.

2. Pajak Penghasilan Pasal 23 adalah pajak yang dipotong atas penghasilan yang berasal dari modal, penyerahan jasa, atau hadiah dan penghargaan, selain yang telah dipotong PPh Pasal 21.

3. PT. AJB Bumiputera 1912 adalah perusahaan asuransi yang bergerak dibidang asuransi jiwa

Secara keseluruhan yang dimaksud dengan judul penelitian ini adalah untuk mengetahui penerapan akuntansi PPh Pasal 23 atas jasa agen di bandingkan dengan SAK danUU No. 36 Tahun 2008.

\section{HASIL ANALISIS DAN PEMBAHASAN}

\subsection{Hasil Analisis}

Penghasilan bruto terkecuali untuk sewa dan jasa yang menggunakan perkiraan penghasilan netto sebagai dasar pemotongan pajak penghasilan $(\mathrm{PPh})$ pasal 23 ayat (1) b huruf c yang di tetapkan oleh Direktorat Jenderal Pajak.

a. Tarif pemotongan adalah :

1. Umum $15 \%$

2. Final (diatur dengan peraturan pemerintah)

b. Saat pemotongan pajak penghasilan adalah pada akhir bulan di lakukan pembayaran atau pada akhir bulan terutangnya penghasilan yang bersangkutan.

Menurut ketentuan dalam surat keputusan Menteri Keuangan nomor 541 /KMK.04 /2000 diatur mengenai penyetoran pajak sebagai berikut :

1. Ketentuan pasal 1 ayat (2) adalah pajak penghasilan (PPh) sebagaimana dimaksud dalam pasal 23 dan pasal 26 undang-undang nomor 7 tahun 1983 tentang pajak penghasilan $(\mathrm{PPh})$ sebagaimana telah diubah terakhir dengan undang-undang nomor 17 tahun 2000, harus disetor paling lambat tanggal 10 (sepuluh) bulan takwim berikutnya setelah bulan saat terutangnya pajak.

2. Ketentuan pasal 2 adalah dalam hal jatuh tempo pembayaran atau penyetoran bertepatan dengan hari libur, maka pembayaran atau penyetoran dapat dilakukan pada hari kerja berikutnya.

3. Pasal 3 adalah pembayaran dan penyetoran pajak dilakukan dikantor pos atau bank badan usaha milik Negara atau bank badan milik daerah, atau bank-bank lain yang ditunjuk oleh Direktur Jenderal Anggaran. 
4. Pasal 4 adalah pembayaran dan penyetoran pajak harus dilakukan dengan menggunakan surat setor pajak (SSP) atau sarana administrasi lain yang ditetapkan oleh Direktur Jenderal Pajak.

Menurut ketentuan undang-undang nomor 16 tahun 2000 KUP diatur mengenai pelaporan pajak sebagai berikut :

1. Ketentuan pasal 3 ayat (3) adalah batas waktu penyampaian surat pemberitahuan adalah:

a. Untuk surat pemberitahuan masa, paling lambat 20 (dua puluh) hari setelah masa pajak.

b. Untuk surat pemberitahuan tahunan, paling lambat 3 (tiga) bulan setelah akhir tahun pajak.

2. Ketentuan pasal 3 ayat (4) adalah Direktur Jenderal Pajak atas permohonan Wajib Pajak dapat memperpanjang jangka waktu penyampaian surat pemberitahuan sebagaimana dimaksud dalam ayat (3) huruf b paling lama 6 (enam) bulan.

3. Ketentuan pasal 4 ayat (1) adalah Wajib Pajak wajib mengisi dan menyampaikan surat pemberitahuan dengan benar, lengkap, jelas dan menandatanganinya.

4. Ketentuan pasal 6 ayat (1) adalah surat pemberitahuan yang di sampaikan langsung oleh Wajib Pajak ke kantor Direktorat Jenderal Pajak harus diberi tanggal penerimaan oleh pejabat yang di tunjuk untuk itu, sedangkan untuk syarat pemberitahuan tahunan harus di berikan juga bukti penerimaan.

5. Ketentuan pasal 6 ayat (2) adalah penyampaian surat pemberitahuan dapat di kirimkan melalui kantor pos secara tercatat atau dengan cara lain yang di atur dengan keputusan Direktorat Jenderal Pajak.

6. Ketentuan pasal 9 ayat (2) adalah kekurangan pembayaran pajak yang terutang berdasarkan surat pemberitahuan tahunan harus di bayar lunas paling lambat tanggal 20 bulan ke-3 setelah tahun pajak atau bagian tahun pajak berakhir, sebelum surat pemberitahuan itu di sampaikan.

7. Ketentuan pasal 10 ayat (1) adalah Wajib Pajak membayar atau menyetor pajak yang terutang di kas Negara melalui Kantor Pos dan atau Bank Usaha Milik Negara atau Bank Badan Usaha Milik Daerah atau tempat pembayaran lain yang di tetapkan oleh Menteri Keuangan.

Sewa dan penghasilan lain sehubungan dengan penggunaan harta dan jasa pihak lain (kecuali sewa dan penghasilan lain sehubungan dengan persewaan tanah dan atau bangunan) di kenakan pemotongan PPh pasal 23 dengan ketentuan sebagai berikut:

1. Sewa dan penghasilan lain sehubungan dengan penggunaan harta khusus angkutan darat adalah sebesar $15 \%$ dari perkiraan penghasilan netto. Besarnya penghasilan netto adalah $40 \%$ dari jumlah bruto tidak termasuk Pajak Pertambahan Nilai (PPN).

2. Sewa dan penghasilan lain sehubungan dengan penggunaan harta, kecuali sewa dan penghasilan lain sehubungan dengan persewaan tanah dan bangunan yang telah di kenakan pajak penghasilan yang bersifat final, berdasarkan peraturan pemerintah No. 29 tahun 1996 dan sewa dan penghasilan lain sehubungan dengan penggunaan harta khusus angkutan darat adalah sebesar 15\% dari perkiraan penghasilan netto. Besarnya perkiraan penghasilan netto adalah $40 \%$ dari jumlah bruto tidak termasuk Pajak Pertambahan Nilai (PPN). 
Tabel 4.1

Contoh Perhitungan PPh Pasal 23 untuk Jasa Broker/Agen pada AJB Bumiputera 1912

\begin{tabular}{|c|c|c|r|}
\hline No & Nama Broker/Agen & Uraian & Jumlah \\
\hline 1 & Tn. A & Premi & $281.097,00$ \\
& & Biaya Polis & $20.000,00$ \\
& & Materai & $6.000,00$ \\
& & Komisi & $56.219,40$ \\
& & PPn & $5.110,85$ \\
& Ny. B & Komisi Netto & $51.109,55$ \\
& & PPh Pasal 23 & $1.022,17$ \\
\hline 2 & & Premi & $372.751,50$ \\
& & Biaya Polis & $20.000,00$ \\
& & Materai & $9.000,00$ \\
& & Komisi & $74.550,30$ \\
& & PPn & $6.777,30$ \\
& & Komisi Netto & $67.773,00$ \\
& & PPh Pasal 23 & $1.355,46$ \\
\hline
\end{tabular}

Sumber : Data perusahaan 2016

Dari tabel 4.1 dapat diketahui bahwa komisi untuk broker/agen ditetapkan oleh pihak asuransi AJB Bumiputera 1912 sebesar 20\% dari jumlah premi yang disetor sedangkan PPh Pasal 23 yang dipotong perusahaan sebesar $2 \%$ dari Komisi setelah dipotong PPn ( komisi netto). Tn. A menerima komisi sebesar Rp. 56.219,40 dan dipotong PPh Pasal 23 sebesar Rp.1.022,17 sedangkan Ny. B menerima komisi sebesar Rp. 74.550,30 dan dipotong PPh Pasal 23 sebesar Rp.1.355,46.

\subsection{Pembahasan}

PPh pasal 23 timbul apabila WP Dalam Negeri dan WP BUT melakukan transaksi yang menimbulkan penghasilan dari modal atau penghasilan dari jasa tertentu. PPh Pasal 23 merupakan pembayaran pajak dimuka yang pada umumnya dapat dikreditkan pada SPT Tahunan oleh WP yang menerima penghasilan.

$\mathrm{PPh}$ Pasal 23 dikenakan atas penghasilan dalam nama dan bentuk apa pun yang dibayarkan, disediakan untuk dibayarkan, atau telah jatuh tempo pembayarannya atas transaksi :

1. Penggunaan modal/uang;

2. Penggunaan harta berwujud atau tidak berwujud;

3. Penggunaan jasa-jasa tertentu.

Setelah pemotongan $\mathrm{PPh}$ pasal 23 di lakukan, maka seluruh jumlah yang telah di potong tersebut wajib di setor ke kas Negara. Di Asuransi AJB Bumiputera 1912 yang bertanggung jawab menyetor PPh pasal 23 ini adalah bagian keuangan pada seksi perpajakan. Penyetoran di lakukan selambat-lambatnya tanggal 10 bulan takwim berikutnya setelah bulan saat terutang pajak. Apabila jatuh pada hari libur, maka penyetoran di lakukan pada hari kerja berikutnya. Penyetoran pajak di laksanakan melalui Kantor Pos atau Bank Usaha Milik Negara atau Bank Milik Daerah. Sarana atau dokumen yang di gunakan dalam penyetoran PPh pasal 23 ini adalah Formulir Surat Setoran Pajak (SSP). Berdasarkan bukti pemotongan pajak penghasilan (PPh) pasal 23 pada Asuransi AJB Bumiputera 1912, maka pelaksanaan penyetoran PPh pasal 23 sudah sesuai dengan ketentuan perundang-undangan perpajakan.

\section{3. $\quad$ Prosedur Pengisian Surat Pemberitahuan PPh Pasal 23}

Dalam pelaksanaan pelaporan PPh pasal 23 di Asuransi AJB Bumiputera 1912 sarana yang di gunakan adalah Surat Pemberitahuan. SPT ada dua macam, yaitu : 
1. SPT Masa, yaitu surat yang di gunakan oleh wajib pajak untuk melaporkan perhitungan dan pembayaran pajak yang terutang dalam suatu masa pajak.

2. SPT Tahunan, yaitu surat yang di gunakan wajib pajak untuk melaporkan perhitungan atau pembayaran pajak yang terutang dalam suatu tahun pajak. Adapun prosedur Pengisian SPT yang di lakukan oleh Asuransi AJB Bumiputera 1912 sebagai WP setelah mengambil sendiri SPT di Kantor Pelayanan Pajak (KPP), yaitu mengisi formulir SPT Masa dengan benar, jelas dan lengkap sesuai dengan petunjuk yang diberikan, karena pengisian yang tidak benar yang mengakibatkan kurang bayar akan dikenakan sanksi perpajakan.

\subsubsection{Prosedur Pelaporan Surat Pemberitahuan PPh Pasal 23}

Adapun batas waktu penyampaian atau Pelaporan SPT Masa PPh pasal 23 yaitu tanggal 20 bulan takwim berikutnya setelah masa pajak berakhir. Jika tanggal 20 jatuh pada hari libur maka SPT Masa disampaikan pada hari kerja sebelumnya. SPT Masa PPh pasal 23 terdiri dari :

a. Lembar ke-1 untuk Kantor Pelayanan Pajak (KPP).

b. Lembar ke-2 untuk Pemotong Pajak.

Sedangkan untuk kelengkapan SPT Masa PPh Pasal 23 ada beberapa lampiran yang harus di cantumkan, yaitu :

1. Daftar bukti potong PPh pasal 23.

2. Lembar ke-2 bukti pemotongan PPh pasal 23.

3. Lembar ke-3 Surat Setoran Pajak (SSP).

Tabel 4.2

Perhitungan PPh Pasal 23 atas Jasa Keagenan menurut Undang-undang Perpajakan

\begin{tabular}{|c|c|c|r|}
\hline No & Nama Broker/Agen & Uraian & \multicolumn{1}{|c|}{ Jumlah } \\
\hline 1 & Tn. A & Premi & $281.097,00$ \\
& & Biaya Polis & $20.000,00$ \\
& & Materai & $6.000,00$ \\
& & Komisi & $56.219,40$ \\
& & PPn & $5.110,85$ \\
& & Komisi Netto & $51.109,55$ \\
& Ny. B & PPh Pasal 23 & $\mathbf{1 . 1 2 4 , 3 8}$ \\
\hline 2 & & Premi & $372.751,50$ \\
& & Biaya Polis & $20.000,00$ \\
& & Materai & $9.000,00$ \\
& & Komisi & $74.550,30$ \\
& & PPn & $6.777,30$ \\
& & Komisi Netto & $67.773,00$ \\
& & PPh Pasal 23 & $\mathbf{1 . 4 9 1}$ \\
\hline
\end{tabular}

Sumber : Data Olahan

Dari tabel 4.2 dapat diketahui bahwa PPh Pasal 23 yang seharusnya dipotong perusahaan sebesar $2 \%$ dari komisi sebelum dipotong PPn ( komisi bruto ) 
Tabel 4.3

Perbedaan Perhitungan PPh Pasal 23 atas Jasa Keagenan menurut Perusahaan dan Undang-undang Perpajakan

\begin{tabular}{|c|c|r|r|r|}
\hline No & Periode & \multicolumn{1}{|c|}{ Perusahaan } & UU Perpajakan & \multicolumn{1}{c|}{ Selisih } \\
\hline 1 & Tn. A & $1.022,17$ & $1.124,38$ & 102,21 \\
\hline 2 & Ny.B & $1.355,46$ & 1.491 & 135,54 \\
\hline
\end{tabular}

Sumber : Data Olahan

Komisi yang diterima Tn.A sebagai broker/agen seharusnya dipotong PPh Pasal 23 sebesar Rp.1.124,38 sedangkan Ny. B dipotong PPh Pasal 23 sebesar Rp.1.491.

\section{KESIMPULAN DAN SARAN}

\subsection{Kesimpulan}

1. Pemungutan Pajak Penghasilan atas penghasilan dari jasa agen yang dilakukan oleh AJB Bumiputera 1912 telah didasarkan pada Undang-UndangNomor 7 Tahun 1983 sebagaimana telah diubah terakhir dengan Undang-Undang Nomor 36 Tahun 2008 tentang Pajak Penghasilan beserta peraturan pelaksanaannya baik itu Peraturan Pemerintah, Peraturan Menteri maupunPeraturan Direktur Jenderal Pajak.

2.. Meskipun dalam pemungutan Pajak Penghasilan atas penghasilan dari jasa keagenan yang dilakukan oleh AJB Bumiputera 1912 telah sesuai dengan peraturanperundangundangan perpajakan namun dalam pelaksanaannya menimbulkan permasalahan. Hal ini terjadi karena PPh pasal 23 atas komisi dipotong sebesar $2 \%$ dari komisi netto, seharusnya dipotong dari komisi bruto maka pembayaran pajak yang dibayar olehwajib pajak pada akhir tahun pajak selalu lebih kecil dari pada pajak yangterutang dalam satu tahun pajak, sehingga setiap tahun kondisi SPT Tahunan PPh selalu menunjukkan kurang bayar,

\subsection{Saran}

1. Staf atau pegawai yang bertugas dalam hal pencatatan berusaha lebih teliti dan cermat dalam menuliskan nama agen, jangan sampai nama agen ditulis terbalik dengan nama agen yang lain, yang memang hampir mirip, juga pada saat pengisian daftar bukti potong PPh Pasal 23.

2. Lebih teliti lagi pada penulisan jumlah nominal, jangan sampai kelebihan atau kekurangan digit angka, serta berusaha mencatat besarnya pungutan dari rekanan pada setiap perubahan yang ada dan langsung di koreksi .

3. Apabila terjadi, maka staf atau pegawai langsung melakukan pembetulan pada Surat Pemberitahuan (SPT) pajak penghasilan (PPh) pasal 23 sebelum dilakukan penyetoran.

\section{DAFTAR PUSTAKA}

Agoes, Sukrisno, 2010, “Akuntansi Perpajakan”, Penerbit Salemba Empat, Jakarta.

Atep A. B, 2011, “Panduan Lengkap Pajak Penghasilan”, Penerbit Visi Media, Jakarta.

Billy I. T, 2010, “Pajak Penghasilan”, Penerbit Graha Ilmu, Bandung.

Erna MS. 2013. Pendekatan Interpretif. http://ernams.wordpress.com/2008/01/07/pendekataninterpretif/. Diakses tanggal 28 September 2014.

Horngren, 2010, “Akuntansi Ed. 06 Jl. 01”, Penerbit Indeks, Jakarta.

Ika Kurniati, 2012, Jurnal Penerapan PPh Pasal 23 atas Jasa Inventaris pada PT. Sinar Sosro 
Indriyawati, 2009, Jurnal Pemungutan Pajak Penghasilan Atas Penghasilan Dari Usaha Jasa Konstruksi di KPP Badan Usaha Milik Negara di Jakarta

Kieso D. E, 2007, “Akuntansi Intermediate”, Penerbit Erlangga, Jakarta.

Moleong, Lexy J. 2013. Metodologi Penelitian Kualitatif, Remaja Rosdakarya. Bandung.

Mardiasmo, 2011, “Perpajakan Edisi Revisi 2011”, Penerbit Andi, Yogyakarta.

Muljono, Djoko, 2010, “Panduan Brevet Pajak”, Penerbit Andi, Yogyakarta.

Rudianto, 2011, “Pengantar Akuntansi”, Penerbit Erlangga, Jakarta.

Soemitro H. R, 2010, “Asas dan Dasar Perpajakan”, Penerbit Refika Aditama, Jakarta.

Sugiyono, 2010, “Metode Penelitian Kuantitatif Kualitatif dan R\&D”, Penerbit Alfabeta, Yogyakarta.

Sumarsan, Thomas, 2012, “Perpajakan Indonesia”, Penerbit Indeks, Jakarta.

Suwardjono, 2010, “Akuntansi Pengantar”, Penerbit BPFE, Yogyakarta.

Undang-Undang RI No. 36 Tahun 2008 tentang Pajak Penghasilan.

Yuniar, 2010, Jurnal Evaluasi Penerapan Pemotongan Pajak Penghasilan Pasal 23 oleh PT. PLN (Persero) Distribusi Jakarta dan Tangerang Area Pelayanan dan Jaringan (APL) Mampang 